Boise State University ScholarWorks

Political Science Faculty Publications and

Presentations

Department of Political Science

$1-1-2016$

\title{
The Engagement Curve: Populism and Political Engagement in Latin America
}

Rafael Piñeiro

Universidad Católica de Uruguay

Matthew Rhodes-Purdy

Boise State University

Fernando Rosenblatt

Universidad Diego Portales, Chile 


\section{PROJECT MUSE}

The Engagement Curve: Populism and Political Engagement in Latin America

Rafael Piñeiro, Matthew Rhodes-Purdy, Fernando Rosenblatt

Latin American Research Review, Volume 51, Number 4, 2016, pp. 3-23 (Article)

Published by Latin American Studies Association

DOI: https://doi.org/10.1353/lar.2016.0046

$\Rightarrow$ For additional information about this article https://muse.jhu.edu/article/639902 


\title{
THE ENGAGEMENT CURVE \\ Populism and Political Engagement in Latin America
}

\author{
Rafael Piñeiro \\ Universidad Católica de Uruguay \\ Matthew Rhodes-Purdy \\ Boise State University \\ Fernando Rosenblatt \\ Universidad de Diego Portales, Chile
}

\begin{abstract}
Considerable research has been conducted on the relationship between socioeconomic inequality and political engagement. However, there is little consensus on the exact nature of the relationship, and considerable variation in the relationship exists even among countries with similar levels of inequality. This lack of clarity in the literature exists because the impact of inequality on engagement is not constant, but changes depending on the strategic choices of political leaders. Populist leaders, who tend to explicitly connect political and socioeconomic exclusion, can activate latent grievances around inequality. Using data from the Latin American Public Opinion Project, we show that inequality leads to disengagement among the poor in most contexts but increases engagement under populist rule. In other words, a primarily structural relationship is mediated by political variables. Even though the severity of inequality is outside the control of any political actor, leaders' reaction to inequality can dramatically alter its impact on mass political behavior.
\end{abstract}

Given that structural inequality is consistently high across Latin America, why do the poor show more political engagement in some polities than in others? Many theories have addressed this relationship, but these studies tend to have variables associated with economic development as their primary causal factors, treating political variables as secondary. For example, Solt (2008) found a direct negative effect of inequality on political engagement in wealthy democracies. Within the democratization literature there have been several studies (e.g., Boix

We are grateful to Jake Bowers, Juan Pablo Luna, Huang Kai-Ping, Anthony Pezzola, Mauro Berazategui, Whitney Lopez-Hardin, Kirk Hawkins, Andrew Gelman, the anonymous reviewers from the Latin American Public Opinion Project (LAPOP) and $L A R R$, and all the participants of the Permanent Seminar at the Instituto de Ciencia Política, Pontificia Universidad Católica de Chile. Additionally, we thank the LAPOP staff for their support. We also thank LAPOP and its major supporters (US Agency for International Development, UN Development Program, Inter-American Development Bank, and Vanderbilt University) for making the data available. We further thank LAPOP for their generous support through a LAPOP Small Grant, which was critical during the early phase of this project. Fernando Rosenblatt acknowledges support from the Chilean Millennium Science Initiative (NS130008). Matthew RhodesPurdy thanks the Fulbright Student Program for supporting his collaboration with this project. 


\section{Latin American Research Review}

2003; Acemoglu and Robinson 2006; Rueschemeyer 2004) that have modeled more contingent relations between inequality and attitudes, but such approaches are extremely limited in their ability to explain different outcomes among countries with similar levels of inequality. In some sense, these limitations are built into the design of so-called structural theories, which envision macro-level, relatively static factors (e.g., inequality, ethnic diversity) as the most important predictors of political phenomena. Even those works inspired by rational choice see "choice" as the relatively automatic response of individuals to exogenous incentives and constraints; they do not envision choice as involving any real agency or contingency at the individual level, beyond random deviation from structurally determined behavioral patterns. Thus, in both structural and rational-choice studies, politics is more an effect than a cause.

These works all share a missing link between inequality and political attitudes: politics. They do not problematize the way that distributive conflict translates into the political arena; the assumption of a constant, direct relationship between structural conditions and mass political attitudes simply cannot account for the array of reactions to inequality that can be observed in Latin America. In this article, we argue that certain political "menus" - that is, leaders who make certain types of appeals and use specific political strategies-can alter the way nationallevel inequality affects the political attitudes of the poor, in turn reshaping the usual relationship between inequality and political engagement. More specifically, we claim that political agents can boost the political engagement of the poor by deliberately politicizing distributive conflict.

Our goal is to fully account for the combined effect of economic structure and political leadership agency on citizens' attitudes and behavior toward the political arena. Structural inequality creates deep social divisions that conflict with the democratic ideal of political equality. The poor lack the resources to transfer their interests to politics, which generates apathy and negates the egalitarian effect of democratic politics. Thus, inequality creates a potential for political conflict, but that conflict remains latent in many contexts because of the inability to solve collective action dilemmas and bear the costs of political action.

Political leaders who combine a combative political strategy with strong redistributive rhetoric can trigger latent conflict. Hence, citizens' attitudes toward politics change from apathy to engagement. In other words, the relationship between inequality and political engagement is not really a line but a curve; the basic structure of this curve is set by structural relations at the national level, but its specific shape in any given society can vary a great deal depending on how political leaders choose to react to it.

\section{INEQUALITY AND ENGAGEMENT IN POLITICS:}

\section{COLLECTIVE ACTION COSTS AS THE MISSING LINK}

Before proceeding with the theoretical framework, we need to specify what we mean by inequality. Inequality is a multilevel concept, composed of severity of inequality at the national level and socioeconomic status (SES) at the individual level. Inequality is endemic in Latin America, and thus there is little variation 
at the national level, with a few notable exceptions, such as Uruguay. Hence, we mostly analyze its effect at the individual level, although we do include nationallevel inequality as a control variable in our statistical analyses.

The effect of inequality on politics has increasingly gained scholarly attention. Solt (2008) conducted an empirical analysis specifically on the effect of inequality on political attitudes, in which he efficiently organized existing theoretical approaches to the topic into three distinct groups. First, he identifies the theory of relative power. This approach assumes that there is a linear relationship between economic power and political power. Possession of resources translates into marginalization of those who have fewer resources. Consequently, it is assumed that the poor will be alienated and will show greater apathy toward politics because their interests are not politicized (Goodin and Dryzek 1980). This also generates low involvement of the rich, since they do not feel their interests are threatened (Solt 2008). In short, high national inequality will have a negative impact on engagement, whereas socioeconomic status will have no impact, with the wealthy and poor equally disengaged in high-inequality societies.

The second approach introduced by Solt (2008) emphasizes conflict. As opposed to the previous perspective, greater distributive conflict leads to greater interest in politics (Meltzer and Richards 1981; Brady 2004). In Solt's $(2008,49)$ words: "Higher levels of inequality cause divergences in political preferences that fuel debates about the appropriate course of policy; these debates then cause higher rates of political mobilization." He also claims that polarization between the rich and the poor increases with inequality. In this perspective we could include Boix (2003) and Acemoglu and Robinson's (2006) works, as their models assume that the distributive conflict automatically translates into the political realm. This approach predicts increased engagement in high-inequality societies but also that SES will have no impact within countries; the intense conflict engendered by inequality should equally galvanize the rich and poor.

A third approach is resource theory. This theory holds that political participation has a cost, and involvement is a function of individuals' resources, that is, their capacity to pay the cost of participating depends on relative income (Ansolabehere, de Figueiredo, and Snyder 2003). Consequently, those who have enough resources (the rich) to pay that cost will have greater involvement than those who do not (the poor) (Solt 2008, 49-50). This approach shares with relative power theory the prediction of a negative relationship between national-level inequality and political engagement, but it further predicts that socioeconomic status will have a positive relationship with engagement. That is, high inequality will generally depress engagement, but this depression will be especially acute among poor citizens and much less severe among the wealthy.

Solt (2008) tests these three different approaches in upper-middle-income democracies. He concludes that results are consistent only with the relative power theory. In a nutshell, lower income quintiles have less political involvement; when inequality is extremely high, the poor are so marginalized that the wealthy cease to participate as well, secure in their social position. In Solt's $(2008,58)$ own words: "Declining political interest, discussion of politics, and participation in elections among poorer citizens with rising inequality attest to the increased ability of rela- 


\section{Latin American Research Review}

tively wealthy individuals to make politics meaningless for those with lower incomes in such circumstances."

What is the problem with these approaches? They do not allow political leaders to try different tactics or strategies when faced with the same circumstances. All of these approaches assume a consistent linear relationship between inequality and political engagement. They all assume that the poor must bear the entire cost of participation. This assumption rules out the possibility that political agents or leaders may have much to gain by paying costs or offering solutions to collective action problems. When the effect of different political strategies is taken into account, the relationship between inequality (in both its dimensions) and engagement becomes highly dependent on political context. Inequality and one's position in the income distribution matter, but their impact is shaped by the kind of political options available. More specifically, in the context of contemporary Latin America, that impact is mediated by the existence of leaders who activate the distributive conflict.

We are not the first to argue that political variables create varying outcomes in response to constant structural conditions. For example, Roberts (2002) examined how such dynamics affect parties and party systems. Several scholars have explained variation in policy outcomes despite similar levels of inequality by introducing political variables. Some have related the political determinants of inequality to redistribution regimes (Huber et al. 2006; Huber, Mustillo, and Stephens 2008; Pribble, Huber, and Stephens 2009; Huber and Stephens 2010; Pribble 2011). It is generally agreed that the poor have significantly more severe collective action problems than do those in higher social strata (Houle 2009). The poor's only advantage lies in their number, which is really no advantage at all because coordination has been historically elusive. This is why those who study democratization have paid significant attention to collective action problems of the poor (Rueschemeyer, Stephens, and Stephens 1992).

These arguments share a common feature. For political outcomes where the behavior of the poor is potentially decisive, the crucial variable is whether and how the poor's collective action dilemma is solved. However, none of these works explicitly includes theories of how these dilemmas get solved, and how different types of solutions may lead to different outcomes within similar structural contexts. They are taken as exogenous explanatory variables rather than dependent variables needing explanation of their own.

Under democracy political leaders are necessary, even essential, for precisely this reason: acting in pursuit of their own interests, they provide solutions to collective action dilemmas for those who cannot provide for themselves. However, there is no guarantee in any given context that leaders will appear to take advantage of latent redistributive conflict. As the vast literature on party-citizen linkages suggests, representation of the poor's redistributive interests cannot be taken for granted (Kitschelt 2000; Piattoni 2001; Stokes 2005; Kitschelt and Wilkinson 2007; Kitschelt et al. 2010; Luna 2014). The highly contingent nature of this interaction between economic structure and political strategy can produce a wide range of outcomes even in similar contexts.

Before discussing the types of strategies that might be best suited for solving 
the collective action dilemmas we have described, we need to briefly clarify our argument. Our argument is not centered on policy outcomes; we have nothing to say about why countries choose different tactics for dealing with inequality, or about why some are more successful than others in this regard. Instead of explaining different levels of inequality or social spending, the conventional approach to structural inequality in the Latin American literature, we try to assess how political strategy interacts with inequality to produce the variation in patterns of engagement that we observe.

\section{TYPES OF POLITICAL STRATEGIES}

Now that we have established the potential importance of political strategies in our argument, an obvious question arises: what sort of strategy is most likely to solve the collective action dilemmas of the poor? Given that our theory involves political strategy, it makes sense to turn to a movement and leaders defined by political strategy: populists. Defining populism is a contentious issue in political science. However, there seems to be considerable support for several key features. Weyland (2001) argued convincingly that, whatever the specific definition, populism is an explicitly political strategy. The definition used here conforms to that insight: we define populism as a political strategy characterized by two features. The first is the assumption that social problems can and should be solved through the political arena. The second is the embrace of an extremely combative political style, in which conflict and open confrontation with one's political adversaries is considered necessary and desirable. ${ }^{1}$ This definition is very similar to that employed by Hawkins (2010), who emphasizes a Manichaean discourse pitting the populist movement against all others. It is also similar to the definition of the "contestatory left" as defined by Weyland, Madrid, and Hunter (2010), although the definition used here is not confined to the political left.

The relevance of populism to the theory here is fairly straightforward. Populists "feel the urge to contest with political enemies" in order to "strengthen the loyalty of mass followers" (Weyland, Madrid, and Hunter 2010, 3). Populist leaders often preside over fractious, poorly institutionalized mass movements, and thus have strong incentives to encourage political action among their followers as a mechanism for maintaining unity and movement cohesion. For those populists whose ideology places them among the political left, the attraction of activating latent disaffection over inequality in order to cement their links to their base is clear.

There is a fundamental divide between leaders and movements that could be placed on the left of the Latin American ideological spectrum. In their book on leftist governments in Latin America, Weyland, Madrid, and Hunter (2010) emphasize the division between reformist leftists and more radical leftist leaders who, in the modern era, have been populist as opposed to socialist or communist parties. The reformist left accepts the current rules of the game (political institu-

1. This definition helps clarify a difficult case: that of Uruguay. The Frente Amplio certainly meets the first criteria but not the second. 


\section{Latin American Research Review}

tions) as given and legitimate, and it seeks to work under those rules to reduce poverty and the negative social effects of inequality through sound policy and a nonconfrontational relationship with the elite. The populist left, however, views inequality, both social and political, as a root cause of social ills and has a confrontational orientation to it and its social manifestations. To the reformist, everyone can eventually win; to the populist, the poor can gain only what the rich lose; this Manichaean view of political competition is, in fact, a defining characteristic of populism to many (Hawkins 2010). The zero-sum nature of social competition envisioned by populist leaders naturally leads to a strong emphasis on contention. This also explains why we choose to accept standard categorizations of the left that lump the highly mobilized Frente Amplio in Uruguay, for example, with elitist leftist parties. In the absence of anti-elite vitriol and the emphasis on a conciliatory approach to dealing with social inequality, we have little reason to expect a dramatic reshaping of the engagement curve (although the intercept of the curve might well be higher in countries with a mobilized but noncontestatory left).

Left-wing populists, perhaps more than any other type of leader, stress the interconnections between political and economic marginalization and the potential to overcome the latter by ending the former. Even though traditional leftist parties could hypothetically fulfill the causal role we ascribe to populist leaders, nothing ensures that such parties will actually seek to mobilize the poor. In fact, in the context of institutionalized party systems the electoral success of such parties can be partly explained by the moderation of their redistributive claims (Hunter 2010; Weyland, Madrid, and Hunter 2010; Levitsky and Roberts 2011). ${ }^{2}$ This argument complements Roberts's (2002) claim that traditional political parties in Latin America have, for a variety of reasons, failed to activate latent concerns over inequality. In some sense our argument poses a caveat to his claim: while parties have not taken advantage of this opportunity, personalistic leaders, particularly those who come from outside the traditional elite, have seized the opportunity to fill the void. Furthermore, the presence of electorally viable populist alternatives with strong redistributive claims is likely to translate economic interests into politics.

To summarize, leaders who favor redistribution should not be expected to produce any change in the relationship between SES and political engagement as posited by resource theory. However, the combination of a combative political strategy and leftist ideology creates a strong incentive for left-wing populists to offer organizational and rhetorical support to the poor, thus allowing them to overcome collective action dilemmas and the prohibitive costs of political action. In essence, we propose a two-dimensional schema (see table 1) for political leaders that is based on both their policy appeals (redistribution or not) and their political strategy (emphasis on mobilization against the elite, or emphasis on ne-

2. Luna, Bidegain, and Reserve $(2011,1)$ introduce a novel account on the impact of "neo-socialist mobilization" on citizens' values: "Cases undergoing 'neo-socialist' mobilization seem to have gained at least some programmatic structure. This took place on the midst of unfavorable historical and structural conditions. ... [P]olarizing political processes can lead to RPG [responsible party government] especially when bottom-up organizing and collective action match leaders' mobilization attempts. Moreover, RPG emerges more often as a result of leftist-driven polarization, which also has to be sustained over a given significantly long period of time." Their work inspires our endeavor and both are intertwined. 
Table 1 Political strategies and the effects on levels of engagement

\begin{tabular}{lll}
\hline & \multicolumn{2}{c}{ Political strategy } \\
\cline { 2 - 3 } & \multicolumn{1}{c}{$\begin{array}{c}\text { Anti-elite } \\
\text { mobilization }\end{array}$} & $\begin{array}{c}\text { No anti-elite } \\
\text { mobilization }\end{array}$ \\
\hline Redistributive claims & Populists & Moderate leftists \\
No redistributive claims & Rightist populists $^{\text {b }}$ & Center and right \\
\hline
\end{tabular}

aThis category includes both demobilized parties (e.g., those of the Concertación in Chile) and mobilized leftist parties that nevertheless take a largely conciliatory tone toward the wealthy and their political representatives (e.g., Frente Amplio in Uruguay or the Brazilian Partido dos Trabalhadores). 'In our time frame this cell is empty, but historically it might include figures such as Carlos Saúl Menem (Argentina) and Alberto Fujimori (Peru) (Weyland 2002).

gotiation and compromise with the elite). We argue that both these elements are necessary to reshape the engagement curve.

This is not a minor question: if moderate leftists have the same effect on the relationship between inequality and political engagement that populists do, it would indicate that poverty reduction policies alone are sufficient to trigger a reduction in the slope of the engagement curve. This allows for a test not only of the theory proposed here but also of its causal mechanism. If redistribution alone were sufficient to moderate the relationship between SES and engagement, it would suggest that policy content was the primary mechanism. However, if moderate leftists and populists do not have the same impact on this relationship, it would provide strong evidence for our argument that explicitly political factors play an important role on leveling the engagement curve between the poor and the rich.

Before we proceed to our empirical analysis, we believe it is necessary to clearly state what we do not mean with our argument as it relates to political strategy. Much has been written in the past few years regarding the pernicious effects of populism on democracy. The wave of populist regimes in Latin America has generated interesting scholarly work analyzing the impact of these types of regimes (e.g., Weyland, Madrid, and Hunter 2010). Our argument does not necessarily contradict their findings. Neither normative nor theoretical implications of the effect these governments have on democratic stability, democratic quality, or the relative health of competitive politics will be derived from our analysis here, except for brief speculation in the conclusion. We do highlight how, under some scenarios in which inequality is rampant and unaddressed by the political system, populist governments can positively affect citizens' political engagement. Second, it is not our purpose to identify the historical conditions that determine the emergence of populist leaders who favor a strong redistributive rhetoric. As mentioned before, populism has arisen at various periods throughout Latin America, and it does not appear to be predicted by national-level inequality in the region. In fact, the appearance of successful populists is more likely predicted by political context than by economic variables (Rhodes-Purdy 2015). Therefore we feel confident that populism's presence or absence can be safely treated as exogenous for the purposes of our analyses. We take no position on the causal antecedents of populism; we simply show how political strategies interact with distributive realities. 


\section{EXPLAINING INTEREST AND INVOLVEMENT IN UNEQUAL SOCIETIES}

\section{Model Specification and Hypotheses}

The most important relationship for our theory is political engagement, regressed on SES:

(1) $Y_{\text {Political Engagement }_{i}}=\beta_{0}+\beta_{1} X_{S E S_{i}}+\mathrm{u}_{i}$.

Because our observations are nested within country-years, we specify a multilevel model:

(2) $Y_{\text {Political Engagement }_{i}}=\beta_{0 K}+\beta_{1 K} X_{\text {SES }_{i}}+\mathrm{u}_{i}$;

(3) $\beta_{0 K}=\gamma_{00}+r_{0 k}$,

where $\gamma_{00}$ is the between-country-year intercept, and $r_{0 k}$ is a random disturbance term for the $k$ th country. Substituting equation 3 into equation 2 leads to the following:

(4) $Y_{\text {Political Engagement }_{i}}=\gamma_{00}+\beta_{1} X_{S E S_{i}}+\mathrm{r}_{0 k}+\mathrm{u}_{i}$.

This type of model, often called a fixed-effects model, is mathematically equivalent to adding a dummy variable for each country year to an ordinary regression model. The addition of level 2 predictors (which we specify shortly) requires the specification presented here.

Our theory suggests that $\beta_{1}$ is not constant but varies depending on the presence or absence of populist leadership. This leads to the following equation:

(5) $Y_{\text {Political Engagement }}=\beta_{g 0}+\beta_{g 1} X_{S E S_{i}}+\mathrm{u}_{i}$

where $g$ is the subscript for each group (either populists and nonpopulists in the two-group analysis, or populists, moderate leftists, and others in the three-group analysis). Our theory suggests a set of hypotheses:

$\mathrm{H}_{1}: \beta_{1 \text { (populist) }}=\beta_{1 \text { (nonpopulist) }}$

$\mathrm{H}_{1}: \beta_{1 \text { (populist) }} \neq \beta_{1 \text { (nonpopulist) }}$

Specifically, we expect the SES coefficient to be significantly lower for populist country-years than for nonpopulist country-years. There are two ways to model such a relationship. The first is multiple group analysis, which involves splitting the sample into populist, nonpopulist, and moderate-leftist country-years, then separately estimating the structural parameters for each sample. The second involves specification of a random slope. This requires the addition of the following to equation set:

(6) $Y_{P E_{i}}=\beta_{0 k}+\beta_{1 k} X_{S E S}+\mathrm{u}_{i}$,

(7) $\beta_{0 k}=\gamma_{00}+\gamma_{01} X_{\text {Populist }_{k}}+\mathrm{r}_{0 k}$, and

(8) $\beta_{1 k}=\gamma_{10}+\gamma_{11} X_{\text {Populist }}+\mathrm{r}_{1 k}$.

Substituting equations 7 and 8 into equation 6 leads to the following:

(9) $Y_{P E_{i}}=\gamma_{00}+\gamma_{01} X_{\text {Populist }_{k}}+\gamma_{10} X_{S E S_{i}}+\gamma_{11}\left(X_{\text {Populist }_{k}} * X_{S E S_{i}}\right)+\mathrm{r}_{0 k}+\mathrm{r}_{1 k}+\mathrm{u}_{i}$.

The random slope model suggests the following hypotheses to test whether the effect of SES varies depending on the presence or absence of populist leadership: 
$\mathrm{H}_{2_{0}}: \gamma_{11}=0$

$\mathrm{H}_{2_{A}}: \gamma_{11} \neq 0$

Where $X_{\text {Populist }_{k}}$ is a dummy variable, coded as 1 if the $k$ th country-year has a populist leader and 0 if not. The extension of this equation for the three-group model is excluded for brevity. In our analysis we focus on the multiple group analysis as the most reliable. In addition to greater flexibility, the relatively small number of country-years in our study gives the random-slope approach fairly low statistical power; we include such analyses primarily as a robustness check.

Finally, we include a full suite of control variables. Of these, the most important is national-level inequality. Because left-wing populists may well be more likely to come to power in high-inequality societies (as conflict theory would suggest), leaving this variable out of analyses could lead to differences in the SES coefficient that would appear to be caused by populism but are in fact the product of higher inequality. We also include national income and a dummy variable for election years (either executive or parliamentary) at the country-year level. At the individual level we include gender, age, ideological self-placement and ideological intensity, and a dummy for urban respondents.

\section{Data}

Individual-level data used in this article are from the 2006-2012 rounds of the LAPOP surveys. Countries included are Argentina, Bolivia, Brazil, Chile, Colombia, Costa Rica, Dominican Republic, Ecuador, El Salvador, Guatemala, Honduras, Mexico, Nicaragua, Panama, Paraguay, Peru, Uruguay, and Venezuela. We also used data from the 1998-2012 waves of LAPOP in Bolivia to provide an additional test of our theory by showing change within a country before and after the election of a populist leader.

\section{Measurement}

Both of our most important variables, political engagement and SES, are abstract and difficult to measure directly. We use confirmatory factor analysis (CFA) techniques to account for this difficulty. We assume that political engagement and SES are latent, unobservable variables, which affect our observed indicators (with some random error). Mathematically this can be expressed as follows:

(10) $y_{i j}=\operatorname{logit}\left(\lambda_{j} \eta+\varepsilon_{i}\right)$, and

(11) $x_{i j}=\lambda_{j} \xi+\delta_{i}$,

where $y_{i j}$ is the $i$ th observation of the $j$ th indicator of the political engagement latent variable $(\eta), x$ is the $j$ th indicator of the latent SES variable $(\xi)$, and $\varepsilon_{i}$ and $\delta_{i}$ are random measurement error terms. We use a logit link function for political engagement because its indicators are binary. We use a series of questions related to political behavior and attitudes as indicators of this latent concept-the clear implication being that individuals who engage in more forms of participation are, almost by definition, more engaged than those who participate in fewer; statistical 
analysis in other contexts supports this (Rhodes-Purdy 2012). The items we use as indicators are attended a municipal council meeting, petitioned local officials, attended a political meeting, attended a protest, retrospective vote, prospective vote, and party ID. Data for party ID and prospective vote were not available in the earlier waves of the Bolivian studies, so the Bolivia-specific analysis does not include those as indicators for any year.

Socioeconomic status is measured by three indicators. We use income (standardized into deciles by country-year due to changes in question scale in the 2012 wave), years of education, and a count of durable goods owned as indicators of the SES latent variable. ${ }^{3}$ The result is a continuous variable with zero mean. We use this variable in two ways in our analyses. First, we include the continuous measure, which assumes a linear relationship between SES and political engagement. To account for potential nonlinearity, we also divide this variable into quintiles, and include dummy variables for membership in the four lowest SES groups (leaving the fifth as the reference category).

Simultaneous estimation of measurement and structural models, especially for models using random slopes, is prohibitively computationally intensive. Therefore, we first estimated the parameters of the CFA model listed earlier, using Stata version 13, and then used its postestimation predict function to get predicted factor scores for both political engagement and SES. In other words, we substitute $\hat{\eta}_{i}$ and $\hat{\xi}_{i}$ for $Y_{\text {Political Engagement }_{i}}$ and $X_{S E S_{i}}$, respectively, in equations 1-9. Results of the CFA are presented in table 2 .

Income inequality across countries is measured by a Gini index of net income inequality (i.e., inequality after taxes and redistribution), taken from Solt's Standardized World Inequality Database (SWID). Solt's data set (version 5) has data for all country-years we use except several 2012 country-years, for which we simply use the 2011 data, and Nicaragua, where data is available only through 2009. We use the 2009 data for both 2010 and 2012 waves in Nicaragua. Solt's data set includes one hundred imputations; therefore, we analyze the data through the standard procedure for handling multiple imputation data sets in Mplus version 7. National income is measured as the log of per capita gross domestic product (GDP) in constant 2005 dollars. ${ }^{4}$

To classify our cases as populists, moderate leftists, and others, we rely on recent literature on the subject (Hawkins 2009; Weyland, Madrid, and Hunter 2010; Lanzaro 2008; Castañeda and Morales 2008). Given the wave of leftist governments in the region, many scholars of Latin American politics have attempted to distinguish moderate leftists from populist leftists. Although they have different criteria, all these studies agree on the classification of each case (when their cases coincide). Our only disagreement with the literature is that we classify Argentina as a case with a populist president. Cristina Fernández has revived the traditions of the Peronist movement. At the same time, she has developed policies and polit-

3. The goods are television, refrigerator, telephone (home and mobile), car, washing machine, microwave, motorcycle, home drinking water, bathroom in the house, computer.

4. Economic Commission for Latin America and the Caribbean, CEPALSTAT, "Estadísticas e indicadores," http://estadisticas.cepal.org/cepalstat/WEB_CEPALSTAT/estadisticasIndicadores.asp?idioma=e. 
Table 2 Estimation results, measurement models

\begin{tabular}{|c|c|c|}
\hline Indicator & Loading estimate (SE) & $p$-value \\
\hline \multicolumn{3}{|l|}{ Political engagement $(n=119,069)$} \\
\hline Attended municipal meeting & $\begin{array}{c}1.39 \\
(.020)\end{array}$ & .000 \\
\hline Petitioned official & $\begin{array}{c}1.00 \\
(.016)\end{array}$ & .000 \\
\hline Attended political meeting & $\begin{array}{c}2.03 \\
(.031)\end{array}$ & .000 \\
\hline Attended protest & $\begin{array}{c}.936 \\
(.017)\end{array}$ & .000 \\
\hline Retrospective vote & $\begin{array}{l}.623 \\
(.013)\end{array}$ & .000 \\
\hline Prospective vote & $\begin{array}{c}1.06 \\
(.015)\end{array}$ & .000 \\
\hline Party ID & $\begin{array}{c}1.88 \\
(.028)\end{array}$ & .000 \\
\hline \multicolumn{3}{|l|}{$\operatorname{SES}(n=102,119)$} \\
\hline Income decile & $\begin{array}{c}1.96 \\
(.010)\end{array}$ & .000 \\
\hline Education & $\begin{array}{c}2.86 \\
(.015)\end{array}$ & .000 \\
\hline Goods owned & $\begin{array}{c}.182 \\
(.001)\end{array}$ & .000 \\
\hline Goodness-of-fit statistics ${ }^{a}$ & Statistic & $p$-value \\
\hline Chi-square ${ }^{b}$ & $4,919.0$ & .000 \\
\hline RMSEA & .054 & .000 \\
\hline CFI & .911 & - \\
\hline
\end{tabular}

${ }^{a}$ Goodness-of-fit statistics not available for SES because model is exactly identified.

bSignificant chi-square statistics usually indicate poor model fit. However, given the sensitivity of this statistic to sample size and the large number of observations, this statistic is not a reliable indicator.

ical strategies based on strong redistributive claims. A list of country-years coded as moderate leftist and populist is presented in table 3. All other control variables (gender, age, urban, ideology) are measured by the relevant LAPOP questions. Ideological intensity is measured by squaring the ideology variable.

\section{Estimation}

The estimations for the regionwide regression models were conducted in MPLUS version 7, using maximum likelihood (ML) with missing values. This technique constructs the likelihood function observation by observation, using whatever information each observation contains (unless all independent variables are missing). This assumes missing at random (MAR), which is risky, as income and ideology are known to often be missing as a function of their values (not missing at random, or NMAR). NMAR models are extremely sensitive to viola- 


\section{Latin American Research Review}

Table 3 List of leaders by type

\begin{tabular}{llll}
\hline \multicolumn{1}{c}{ Leader } & \multicolumn{1}{c}{$\begin{array}{c}\text { Leadership } \\
\text { type }\end{array}$} & Country & $\begin{array}{c}\text { Waves in } \\
\text { power }\end{array}$ \\
\hline Cristina Fernández & Populist & Argentina & 2008-2012 \\
Evo Morales & Populist & Bolivia & $2006-2012$ \\
Rafael Correa & Populist & Ecuador & $2008-2012$ \\
Daniel Ortega & Populist & Nicaragua & $2008-2012$ \\
Hugo Chávez & Populist & Venezuela & All \\
Lula da Silva & Moderate leftist & Brazil & $2006-2010$ \\
Dilma Rousseff & Moderate leftist & Brazil & 2012 \\
Ricardo Lagos & Moderate leftist & Chile & 2006 \\
Michelle Bachelet & Moderate leftist & Chile & $2006-2010$ \\
Fernando Lugo & Moderate leftist & Paraguay & $2008-2012$ \\
Tabaré Vázquez & Moderate leftist & Uruguay & $2006-2010$ \\
José Mujica & Moderate leftist & Uruguay & 2012 \\
\hline
\end{tabular}

Note: Years refer to the LAPOP wave, not actual years in power. Néstor Kirchner is excluded from analysis because Argentina was not included in the 2006 LAPOP wave, the last in which he was in power.

tions of normality, and we feel that avoiding attempts to model these missingness functions is the safer choice (Allison 2012, 20). For the multiple group analyses, we use Wald tests to determine whether the coefficients for SES are significantly different across populists and nonpopulists.

\section{Analysis of Results}

A brief restatement of the expectations of different theories is useful here. The three theories we have presented make clear predictions about relationships between inequality, SES, and engagement. These predictions are presented in table 4.

Our argument can be summarized as follows: We concur with resource theory regarding the role of access to mobilization resources in the relationship between SES, inequality, and engagement. However, our argument suggests an important modification to resource theory: the inability of the poor to pay the costs of participation is not constant because political leaders can step in to help bear the burden, thus moderating the impact of SES on engagement. In other words, political leaders who successfully mobilize the poor can push their societies toward dynamics closer to conflict theory than to either resource or relative power theory.

We begin by presenting descriptive statistics in table 5 . Specifically, we present the mean predicted factor scores for the engagement latent variable for the lowest and highest SES quintiles, by country and by populist and nonpopulist countryyears.

The difference between populist and nonpopulist country-years is considerable. The discrepancy in engagement between the poorest and the wealthiest in populist countries is much larger in nonpopulist countries. This immediately suggests that populism has some impact on how SES and political engagement relate, although such a simple comparison cannot provide strong evidence. Anal- 
Table 4 Summary of theoretical predictions

\begin{tabular}{llll}
\hline & $\begin{array}{c}\text { Relative } \\
\text { power }\end{array}$ & Conflict & Resource \\
\hline SES coefficient & Null & Null & Negative \\
Inequality & Negative & Positive & Negative \\
\hline
\end{tabular}

Table 5 Descriptive statistics, mean engagement levels

\begin{tabular}{lrrr}
\hline & 1st SES quintile & 5th SES quintile & Difference \\
\hline Mexico & -.001 & .025 & -.026 \\
Guatemala & -.169 & -.094 & -075 \\
El Salvador & -.096 & .104 & -.200 \\
Honduras & -.016 & .175 & -.191 \\
Nicaragua & .050 & .214 & -.164 \\
Costa Rica & -.195 & .003 & -.198 \\
Panama & -.132 & -.028 & -.104 \\
Colombia & -.077 & .088 & -.165 \\
Ecuador & -.168 & -.009 & -.159 \\
Bolivia & .091 & .087 & .004 \\
Peru & .011 & -.057 & .068 \\
Paraguay & -.044 & .228 & -.272 \\
Chile & -.252 & -.214 & -.038 \\
Uruguay & .090 & .288 & -.198 \\
Brazil & -.060 & -.005 & -.055 \\
Venezuela & -.027 & .064 & -.091 \\
Argentina & -.061 & -.067 & .006 \\
Dominican Republic & .543 & .359 & .175 \\
Nonpopulists & -.025 & .051 & -.076 \\
Populists & .020 & .028 & -.008 \\
\hline
\end{tabular}

yses of the multiple group model developed earlier provides far more convincing evidence; results are presented in tables 6 and 7.

Countries without populist leaders largely follow conventional social science expectations about the relationship between socioeconomic status and political engagement. ${ }^{5}$ As the results presented in tables 6 and 7 show, SES is positively associated with political engagement; the rich participate more than the poor to a significant degree. However, our analysis introduces a significant caveat. While the conventional treatment of the relationship between society and politics as unidirectional and invariant across contexts may be reasonable in developed societies, it is questionable in a context of developing societies such as those in Latin America. The stakes of politics are substantially higher in Latin America

5. These countries are thus fairly compatible with Solt's (2008) relative power framework as well as resource theory. The latter differs from relative power theory only in the extent to which the rich meet the disengagement of the poor with disengagement of their own or continued participation. Both imply a positive linear relationship; the former simply has a somewhat shallower slope than the latter. 


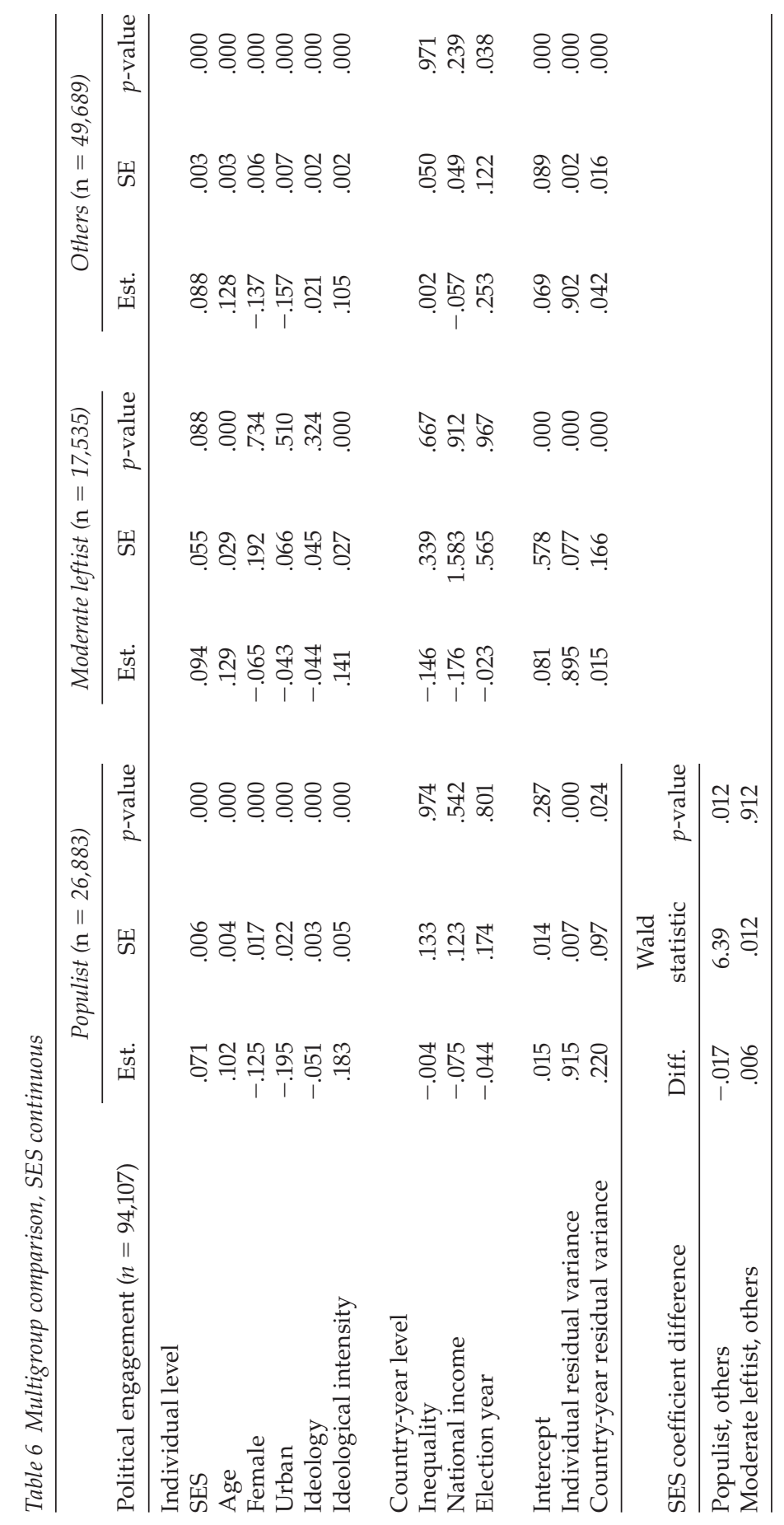


Table 7 Multigroup comparison, SES categorical by quintiles

\begin{tabular}{|c|c|c|c|c|c|c|}
\hline \multirow[b]{2}{*}{ Political engagement $(n=94,107)$} & \multicolumn{3}{|c|}{ Populist $(\mathrm{n}=26,883)$} & \multicolumn{3}{|c|}{ Others $(\mathrm{n}=67,224)$} \\
\hline & Est. & SE & $p$-value & Est. & SE & $p$-value \\
\hline \multicolumn{7}{|l|}{ Individual level } \\
\hline SES, 1st quintile & -.217 & .040 & .000 & -.251 & .010 & .000 \\
\hline SES, 2nd quintile & -.092 & .026 & .000 & -.181 & .010 & .000 \\
\hline SES, 3rd quintile & -.080 & .032 & .012 & -.159 & .012 & .000 \\
\hline SES, 4th quintile & -.043 & .076 & .576 & -.109 & .014 & .000 \\
\hline Age & .103 & .007 & .000 & .127 & .002 & .000 \\
\hline Female & -.126 & .050 & .013 & -.120 & .006 & .000 \\
\hline Urban & -.194 & .082 & .017 & -.128 & .006 & .000 \\
\hline Ideology & -.051 & .008 & .000 & .004 & .002 & .024 \\
\hline Ideological intensity & .184 & .025 & .000 & .115 & .002 & .000 \\
\hline \multicolumn{7}{|l|}{ Country-year level } \\
\hline Inequality & -.004 & .617 & .995 & -.062 & .043 & .151 \\
\hline National income & -.073 & .492 & .881 & -.089 & .049 & .066 \\
\hline Election year & -.045 & .547 & .935 & .133 & .091 & .143 \\
\hline Intercept & .301 & .137 & .028 & .234 & .066 & .000 \\
\hline Individual disturbance variance & .915 & .015 & .000 & .902 & .002 & .000 \\
\hline Country-year disturbance variance & .015 & .065 & .814 & .046 & .015 & .001 \\
\hline SES coefficient difference & Diff. & $\begin{array}{c}\text { Wald } \\
\text { test }\end{array}$ & $p$-value & & & \\
\hline SES, 1st quintile & .034 & .697 & .404 & & & \\
\hline SES, 2nd quintile & .089 & 10.2 & .001 & & & \\
\hline SES, 3rd quintile & .079 & 5.41 & .020 & & & \\
\hline SES, 4th quintile & .066 & .743 & .389 & & & \\
\hline Intercept & .067 & .197 & .657 & & & \\
\hline
\end{tabular}

than in the industrialized world, where the acceptable policy space is relatively well defined. Absolute inequality matters, but not as a variable. Rather, it is important because it creates a pool of alienation and resentment that can be tapped under the some circumstances. However, while this resource remains dormant, societies do tend to follow patterns of engagement in line with the conventional predictions; that is, the rich tend to participate more in politics.

Such dynamics, however, can change rather quickly. The potential for redistributive conflict, and the hesitance of traditional political elites to confront it, gives ambitious outsiders a ready resource to challenge the existing order. Highly unequal societies that experience mobilization political strategies tend to follow the dynamics predicted by conflict theory. The slope of the engagement curve is significantly shallower among populist country-years than among those without populist leaders. The results in table 7 are particularly clear. In substantive terms, this means that the relationship between SES and political engagement is considerably weaker in countries with populist rulers. What is even more interesting is 
the slope for moderate leftists, which is actually steeper than in either populist or non-redistributive country-years.

In table 6, the slope of SES is roughly 20 percent smaller in populist countryyears than in those without populists. In table 7, the impact of being in the secondlowest SES quintile is twice as large in nonpopulist country-years as in populist country-years. Table 6 also conforms to conflict theory because all five SES quintiles had higher predicted levels of support in populist countries, although differences were larger in the lower classes. Random slope models largely confirmed these analyses, although the difference for SES was not statistically significant when treated as continuous (this was likely a result of low statistical power). These results of those analyses are presented in tables 8 and 9.

In simple terms, economic inequality predicts political inequality most directly in countries that are governed by the moderate left, then in countries governed by leaders who do not offer redistribution, or in populist countries. The difference is just short of statistical significance (at the .05 level), but this finding is still interesting. The implication is that, when redistribution is offered without a mobilization political strategy, the poor actually withdraw from the political arena (perhaps content that their interests are being represented). Conversely, the rich, perhaps feeling threatened, increase their political activity in this scenario. Whatever the explanation, these analyses strongly support the importance of political strategy for moderating the relationship between economic inequality and political attitudes.

A simple comparison of differences across country-years is highly suggestive, but attributing the effect directly to populist leadership is difficult; some factor that predicts both populism and a reshaping of the engagement curve could be

Table 8 Random slope multilevel model, SES continuous

\begin{tabular}{lccc}
\hline Political engagement $(n=94,107)$ & Est. & SE & $p$-value \\
\hline Individual level & & & \\
SES & .093 & .014 & .000 \\
Age & .122 & .002 & .000 \\
Female & -.122 & .004 & .000 \\
Urban & -.161 & .005 & .000 \\
Ideology & -.013 & .002 & .000 \\
Ideological intensity & .135 & .002 & .000 \\
Country-year level & & & \\
Populist & -.063 & .102 & .537 \\
Populist $\times$ SES & -.027 & .025 & .279 \\
Inequality & & & .132 \\
National income & -.061 & .041 & .005 \\
Election year & -.110 & .039 & .163 \\
Intercept & .095 & .068 & .004 \\
Individual disturbance variance & & & .000 \\
Country-year disturbance variance & .161 & .047 & .000 \\
\hline
\end{tabular}


Table 9 Random slope multilevel model, SES categorical by quintiles

\begin{tabular}{lccc}
\hline Political engagement $(n=94,107)$ & Est. & SE & $p$-value \\
\hline Individual level & & & \\
SES, 1st quintile & -.262 & .035 & .000 \\
SES, 2nd quintile & -.189 & .023 & .000 \\
SES, 3rd quintile & -.162 & .018 & .000 \\
SES, 4th quintile & -.111 & .014 & .000 \\
& & & \\
Age & .121 & .002 & .000 \\
Female & -.123 & .005 & .000 \\
Urban & -.153 & .005 & .000 \\
Ideology & -.013 & .002 & .000 \\
Ideological intensity & .135 & .002 & .000 \\
& & & \\
Country-year level & & & \\
Populist & -.144 & .108 & .182 \\
Populist $\times$ SES, 1st quintile & .061 & .072 & .396 \\
Populist $\times$ SES, 2nd quintile & .103 & .053 & .052 \\
Populist $\times$ SES, 3rd quintile & .085 & .034 & .011 \\
Populist $\times$ SES, 4th quintile & .069 & .027 & .011 \\
Inequality & & & \\
National income & -.066 & .039 & .093 \\
Election year & -.118 & .041 & .004 \\
& .091 & .074 & .218 \\
Intercept & & & \\
Individual disturbance variance & .301 & .046 & .004 \\
Country-year disturbance variance & .035 & .0010 & .000 \\
\hline
\end{tabular}

driving the results. The most likely suspect is national-level inequality, for which we control, but there could well be others. To address this, we also conducted an analysis of one country, Bolivia, for which data are available for several years before and after the rise of Evo Morales. This model has identical measures to those presented earlier except for two indicators of engagement that were not available. Additionally, we drop country-level predictors and use a simple fixedeffects model, where the idiosyncratic effects of such predictors are controlled for via the year-level residuals. Results from these analyses are presented in tables 10 and 11.

These results conform to those presented earlier. The coefficient of SES was reduced by three-fifths after Morales took power. The reduction in the negative impact of membership in the first SES quintile was a similar magnitude, while that of second quintile membership was reduced by three-fourths (both differences were statistically significant). Short of a true experiment, this is perhaps the closest one can get to a direct test the way populism shapes the engagement curve. And, as in our cross-sectional analyses, the impact is clear: countries with populist presidents adhere more to conflict theory than to either of Solt's alternatives. 
Table 10 Bolivia before and after Morales comparison, SES continuous

\begin{tabular}{|c|c|c|c|c|c|c|}
\hline \multirow{2}{*}{$\begin{array}{l}\text { Political engagement } \\
\qquad(n=24,645)\end{array}$} & \multicolumn{3}{|c|}{ Before Morales $(\mathrm{n}=15,452)$} & \multicolumn{3}{|c|}{ After Morales $(\mathrm{n}=9,193)$} \\
\hline & Est. & SE & $p$-value & Est. & SE & $p$-value \\
\hline \multicolumn{7}{|l|}{ Individual level } \\
\hline SES & .080 & .009 & .000 & .030 & .010 & .004 \\
\hline Age & .153 & .018 & .000 & .138 & .010 & .000 \\
\hline Female & -.284 & .016 & .000 & -.176 & .021 & .000 \\
\hline Urban & -.374 & .018 & .000 & -.013 & .012 & .308 \\
\hline Ideology & -.099 & .013 & .000 & -.140 & .018 & .000 \\
\hline Ideological intensity & .243 & .030 & .000 & .270 & .039 & .000 \\
\hline Intercept & .909 & .126 & .000 & .830 & .111 & .000 \\
\hline $\begin{array}{l}\text { Individual-level disturbance } \\
\text { variance }\end{array}$ & .927 & .011 & .000 & .954 & .014 & .000 \\
\hline $\begin{array}{l}\text { Year-level disturbance } \\
\text { variance }\end{array}$ & .063 & .037 & .093 & .012 & .009 & .176 \\
\hline SES coefficient difference & Diff. & Wald test & $p$-value & & & \\
\hline Before/after Morales & .050 & 13.61 & .000 & & & \\
\hline
\end{tabular}

Table 11 Bolivia before and after Morales comparison, SES categorical by quintile

\begin{tabular}{|c|c|c|c|c|c|c|}
\hline \multirow{2}{*}{$\begin{array}{l}\text { Political engagement } \\
\qquad(n=24,645)\end{array}$} & \multicolumn{3}{|c|}{ Before Morales $(\mathrm{n}=15,452)$} & \multicolumn{3}{|c|}{ After Morales $(\mathrm{n}=9,193)$} \\
\hline & Est. & SE & $p$-value & Est. & SE & $p$-value \\
\hline \multicolumn{7}{|l|}{ Individual level } \\
\hline SES, 1st quintile & -.227 & .028 & .000 & -.107 & .034 & .002 \\
\hline SES, 2nd quintile & -.128 & .026 & .000 & -.039 & .032 & .217 \\
\hline SES, 3rd quintile & -.083 & .025 & .001 & -.015 & .030 & .618 \\
\hline SES, 4th quintile & -.025 & .025 & .316 & -.014 & .030 & .641 \\
\hline Age & .156 & .018 & .000 & .140 & .010 & .000 \\
\hline Female & -.284 & .016 & .000 & -.174 & .021 & .000 \\
\hline Urban & -.372 & .018 & .000 & -.013 & .012 & .292 \\
\hline Ideology & -.220 & .030 & .000 & -.300 & .039 & .000 \\
\hline Ideological intensity & .240 & .030 & .000 & .272 & .039 & .000 \\
\hline Intercept & .465 & .106 & .000 & .123 & .060 & .040 \\
\hline $\begin{array}{l}\text { Individual-level disturbance } \\
\text { variance }\end{array}$ & .927 & .011 & .000 & .954 & .014 & .000 \\
\hline \multirow[t]{2}{*}{$\begin{array}{l}\text { Year-level disturbance } \\
\text { variance }\end{array}$} & .064 & .038 & .093 & .012 & .009 & .176 \\
\hline & \multicolumn{3}{|c|}{ Before/after Morales } & & & \\
\hline SES coefficient difference & Diff. & Wald test & $p$-value & & & \\
\hline SES, 1st quintile & -.120 & 7.39 & .007 & & & \\
\hline SES, 2nd quintile & -.089 & 4.67 & .031 & & & \\
\hline SES, 3rd quintile & -.068 & 3.09 & .079 & & & \\
\hline SES, 4th quintile & -.011 & .075 & .784 & & & \\
\hline Intercept & .342 & 7.87 & .005 & & & \\
\hline
\end{tabular}




\section{CONCLUSIONS}

This article has shown the effects of political strategies in shaping the connection between inequality and political engagement. Latin America provides a unique opportunity to study this relationship because it introduces an empirical and a theoretical puzzle. Absolute inequality is relatively constant and pervasive across countries but shows enormous variation in terms of engagement. The fact that the key independent variable does not vary while outcomes do makes Latin America uniquely suited for opening the black box of how structural conditions interact with political offers to shape patterns of political activism. Moreover, by cracking open the black box, we realize that this relationship is highly contingent on the choices of political agents. This contingency allows us to explain the presence of greater engagement among the poor, counter to the predictions of the relative power theory of generally depressed involvement across social strata, found by Solt (2008), given constant high inequality.

Our analysis implies the need for a more nuanced understanding of the effects of populism in Latin America vis-à-vis democratic quality. While we do not include any explanation of when and where populists succeed in our theory, we can speculate a bit in light of our conclusions. Concerns over populism's disregard for liberal norms of political competition have often obscured the contribution that some populist movements make to bringing formerly excluded sectors of society into the political arena. Developing democracies face the following dilemma: democracy there is either boring (i.e., the policy space is tightly constrained to similar and moderate alternatives) and stable or intense and unstable (Rosenblatt 2013). Populism is not an accident of history but a reaction to the failure of more "responsible" or "traditional" political actors to open the democratic arena to all sectors of society (Rhodes-Purdy 2015). No matter how much moderate leftists may be committed to ameliorating inequality, if they fail to generate actual significant changes, they lack the political backing to survive crises; this flaw is of their own making, as they specifically avoid building strong mobilized bases (with a few notable exceptions). When considered in tandem with our analyses of the way moderate leftist leaders affect the engagement curve, this dynamic becomes quite troubling, because such movements are inherently unsustainable. Venezuela under Punto Fijo is a good historical example. Decades of successive Acción Democrática administrations engaged in redistribution. However, when crisis struck in the 1980s and 1990s, the traditional Venezuelan left was eventually felled by its elitist image, supplanted by a movement that offered the poor a chance not merely to have a larger slice of the national treasure but also win those gains for themselves through political participation.

In other words, populist leaders, while certainly capable of destabilizing societies with their combative style and Manichaean rhetoric, can also force societies to confront problems that often have festered for generations. Although in the immediate term this may mean heightened conflict and concomitant instability (and a potential depression of democratic quality), it may also help to begin tearing down structural inequality. 


\section{REFERENCES}

Acemoglu, Daron, and James Robinson

2006 Economic Origins of Dictatorship and Democracy. New York: Cambridge University Press.

Allison, Paul D.

2012 "Handling Missing Data by Maximum Likelihood." Paper No. 312-2012, SAS Global Forum 2012. http://www.statisticalhorizons.com/wp-content/uploads/ MissingDataByML.pdf.

Ansolabehere, Stephen, John M. de Figueiredo, and James M. Snyder Jr.

2003 "Why Is There So Little Money in US Politics?" Journal of Economic Perspectives 17 (1): 105-130.

Boix, Carles

2003 Democracy and Redistribution. Cambridge: Cambridge University Press.

Brady, Henry E.

2004 "An Analytical Perspective on Participatory Inequality and Income Inequality." In Social Inequality, edited by Kathryn Neckerman, 667-702. New York: Russell Sage Foundation.

Castañeda, Jorge G., and Marco A. Morales, eds.

2008 Leftovers: Tales of the Latin American Left. New York: Routledge.

Goodin, Robert, and John Dryzek

1980 "Rational Participation: The Politics of Relative Power." British Journal of Political Science 10 (3): 273-292.

Hawkins, Kirk

2009 "Is Chávez Populist? Measuring Populist Discourse in Comparative Perspective." Comparative Political Studies 42 (8): 1040-1067.

2010 Venezuela's Chavismo and Populism in Comparative Perspective. Cambridge: Cambridge University Press.

Houle, Christian

2009 "Inequality and Democracy: Why Inequality Harms Consolidation but Does Not Affect Democratization." World Politics 61 (4): 589-622.

Huber, Evelyne, Thomas Mustillo, and John D. Stephens

2008 "Politics and Social Spending in Latin America." Journal of Politics 70 (2): 420-436. doi: $10.2307 / 30218897$.

Huber, Evelyne, Francois Nielsen, Jenny Pribble, and John D. Stephens

2006 "Politics and Inequality in Latin America and the Caribbean." American Sociological Review 71 (6): 943-963.

Huber, Evelyne, and John D. Stephens

2010 "Successful Social Policy Regimes? Political Economy, Politics, and Social Policy in Argentina, Chile, Uruguay, and Costa Rica." In Democratic Governance in Latin America, edited by Timothy Scully and Scott Mainwaring, 155-209. Stanford, CA: Stanford University Press.

Hunter, Wendy

2010 The Transformation of the Workers' Party in Brazil, 1989-2009. Cambridge: Cambridge University Press.

Kelly, Nathan, and Jana Morgan

2011 "Market Conditioning, Redistribution and Income Inequality in Latin America and the Caribbean." Paper presented at the American Political Science Association meeting, Seattle, WA, September $1-4$.

Kitschelt, Herbert

2000 "Linkages between Citizens and Politicians in Democratic Polities." Comparative Political Studies 33 (6-7): 845-879.

Kitschelt, Herbert, Kirk Hawkins, Juan Pablo Luna, Guillermo Rosas, and Elizabeth

Zechmeister

2010 Latin American Party Systems, Comparative Politics. New York: Cambridge University Press.

Kitschelt, Herbert, and Steven Wilkinson

2007 "Citizen-Politician Linkages: An Introduction." In Patrons, Clients and Policies: Pat- 
terns of Democratic Accountability and Political Competition, edited by Herbert KitLanzaro, Jorge schelt and Steven I. Wilkinson, 1-49. Cambridge: Cambridge University Press.

2008 "La social democracia criolla." Nueva Sociedad 217: 40-58.

Levitsky, Steven, and Kenneth M. Roberts, eds.

2011 The Resurgence of the Latin American Left. Baltimore, MD: Johns Hopkins University Press.

Luna, Juan Pablo

2014 Segmented Representation: Political Party Strategies in Unequal Democracies. Oxford Studies in Democratization. Oxford: Oxford University Press.

Luna, Juan P., Germán Bidegain, and Roody Reserve

2011 "Flourishing in the Desert? Socio-Political Polarization and the Programmatic Structuring of (some) Andean Party Systems." Paper presented at the conference "Polarization and Conflict in Latin America," Institut Català Internacional per la Pau, Barcelona, May 5.

Meltzer, Allan, and Scott Richards

1981 "A Rational Theory of the Size of Government." Journal of Political Economy 89 (5): 914-927.

Piattoni, Simona, ed.

2001 Clientelism, Interests, and Democratic Representation: The European Experience in Historical and Comparative Perspective. Cambridge: Cambridge University Press.

Pribble, Jennifer

2011 "Worlds Apart: Social Policy Regimes in Latin America." Studies in Comparative International Development 46 (2): 191-216.

Pribble, Jennifer, Evelyne Huber, and John D. Stephens

2009 "Politics, Policies, and Poverty in Latin America." Comparative Politics 41 (4): 387-407.

Rhodes-Purdy, Matthew

2012 "Participation Paradoxes: Voting, Contention and Support for Democracy." Paper presented at the annual meeting of the American Political Science Association, New Orleans, LA.

2015 "Participatory Populism: Theory and Evidence from Bolivarian Venezuela." Political Research Quarterly 68 (3): 415-427.

Roberts, Kenneth

2002 "Social Inequalities without Class Cleavages in Latin America's Neoliberal Era." Studies in Comparative International Development 36 (4): 3-33.

Rosenblatt, Fernando

2013 "How to Party? Static and Dynamic Party Survival in Latin American Consolidated Democracies." PhD diss., Instituto de Ciencia Política, Pontificia Universidad Católica de Chile, Santiago.

Rueschemeyer, Dietrich

2004 "Addressing Inequality." Journal of Democracy 15 (4): 76-90.

Rueschemeyer, Dietrich, Evelyne Stephens, and John Stephens

1992 Capitalist Development and Democracy. Chicago: University of Chicago Press.

Solt, Frederick

2008 "Economic Inequality and Democratic Political Engagement." American Journal of Political Science 52 (1): 48-60.

Stokes, Susan C.

2005 "Perverse Accountability: A Formal Model of Machine Politics with Evidence from Argentina." American Political Science Review 99 (3): 315-325.

Weyland, Kurt

2001 "Clarifying a Contested Concept: Populism in the Study of Latin American Politics." Comparative Politics 34 (1): 1-22.

2002 The Politics of Market Reform in Fragile Democracies: Argentina, Brazil, Peru, and Venezuela. Princeton, NJ: Princeton University Press.

Weyland, Kurt, Raúl L. Madrid, and Wendy Hunter

2010 Leftist Governments in Latin America. New York: Cambridge University Press. 